\title{
IMMUNOHISTOCHEMICAL PROFILE OF OVARIAN GERM CELL TUMOURS
}

\author{
Roshny Jacob ${ }^{1}$, Geetha Sukumaran ${ }^{2}$
}

${ }^{1}$ Assistant Professor, Department of Pathology, Government Medical College, Trivandrum. ${ }^{2}$ Associate Professor, Department of Pathology, Government Medical College, Trivandrum.

\begin{abstract}
BACKGROUND

Germ cell tumours of ovary comprise a heterogeneous group of tumours with distinct morphological features. Diagnosis of tumours like teratoma can be made on morphological basis, but that of other germ cell tumours would need additional help of immunohistochemical (IHC) markers. But many a time, IHC markers fail to yield the expected results.

The aim of this study is to compare the results of the various conventional IHC stains used as markers in common ovarian germ cell tumours.
\end{abstract}

\section{MATERIALS AND METHODS}

Ovarian germ cell tumours which were reported from the Department of Pathology, Government Medical College, Trivandrum during a period of one year were reviewed and chosen for this case series study. Routine Haematoxylin and Eosin staining and later a panel of selected immunohistochemical markers like PLAP, CD-117, OCT-4, CK, CD-30 and AFP were used in each case.

\section{RESULTS}

Fifty-five cases of germ cell tumours were received during the study period. Teratoma was the most common tumour (65.45\%). There were nineteen cases of malignant germ cell tumours, of which thirteen cases were chosen for immunohistochemical study. Every tumour was stained with all the above-mentioned markers and their results were compared with the expected findings in each case. Positivity of Dysgerminoma for its IHC markers- PLAP, CD-117 and OCT-4 were $66.6 \%, 44.4 \%$ and $77.7 \%$ respectively. Among the three cases of Yolk sac tumour, only one was positive (33.3\%) for AFP; $66.6 \%$ cases of Embryonal Carcinoma were positive for OCT-4, whereas none was positive for CD-30.

\section{CONCLUSION}

Teratoma, the commonest germ cell tumour was not included in the study due to the minimal role played by IHC in its diagnosis. Germ cell tumours other than Teratoma were relatively rare. The usual IHC markers employed in their diagnosis were found to be not specific and yielded aberrant results. This fact calls for the use of newer, more specific markers for the diagnosis of ovarian germ cell tumours.

\section{KEYWORDS}

Immunohistochemistry, Markers, Ovarian Germ Cell Tumours.

HOW TO CITE THIS ARTICLE: Jacob R, Sukumaran G. Immunohistochemical profile of ovarian germ cell tumours. J. Evolution Med Dent. Sci. 2017;6(61):4459-4462, DOI: 10.14260/Jemds/2017/964

\section{BACKGROUND}

Germ cell tumours form a varied group of benign and malignant neoplasms derived from primordial germ cells occurring in a variety of sites, both gonadal and extra gonadal. In ovary, they constitute $15 \%-20 \%$ of all neoplasms ${ }^{1}$ and $3 \%$ - $5 \%$ of malignant tumours. Their correct diagnosis is important and challenging as they differ in their behaviour, presentation and histological appearance.

Benign Cystic Teratoma is the most common germ cell tumours that tend to be grossly and microscopically distinctive, as they contain skin and skin appendages as well as benign tissues derived from other germ cell layers. As morphological diagnosis is easy, immunohistochemistry is rarely required for its diagnosis.

Financial or Other, Competing Interest: Dr. Jacob reports grants from State Board of Medical Research, Government of Kerala, during the conduct of the study.

Submission 23-06-2017, Peer Review 19-07-2017,

Acceptance 24-07-2017, Published 31-07-2017.

Corresponding Author:

Dr. Geetha Sukumaran,

Associate Professor,

Department of Pathology,

Government Medical College, Trivandrum.

E-mail: gsukumaran08@gmail.com

DOI: $10.14260 /$ jemds/2017/964
Dysgerminoma is said to show a $100 \%$ positivity for PLAP, but recent studies counter this. ${ }^{2,3}$ CD-117 positivity in dysgerminoma helps to differentiate it from closely related tumours $4,5,6,7$ and also helps in choosing treatment regimens. ${ }^{7}$ Other markers which claim usefulness are OCT-4, SALL-4, NANOG, etc. Alpha-fetoprotein remains still as the most widely used marker for Yolk sac tumour, which showcases a variety of patterns. ${ }^{8}$ Another stain used is Glypican-3.9,10,11,12 The negative staining for EMA, WT1, CD1513 and CK714 also helps.

OCT-415 and CD-3016 are the most useful immunehistochemical stains used in embryonal carcinoma. The carcinoma cells show diffuse strong nuclear staining for OCT4 and diffuse strong membrane staining for CD-30. Both embryonal carcinoma and dysgerminoma stain for OCT-4,15 but only embryonal carcinoma stains for CD-30. Moreover, negative staining for $\mathrm{CD}-117$ differentiates embryonal carcinoma from dysgerminoma. ${ }^{1}$ Embryonal carcinoma is negative for D2-40 and positive for cytokeratin, SALL-4 and PLAP.

In choriocarcinoma, trophoblastic cells stain for HCG, CD10 and cytokeratin, but are negative for EMA. Inhibin and HCG stains syncytiotrophoblasts selectively. Results with Inhibin is better than HCG, as there is less background staining. ${ }^{17,18}$ 
The use of immunohistochemical stains is imperative in the diagnosis of germ cell tumours. Since the IHC markers are varied, the choice of correct markers is challenging in view of the limited study material and the financial expenses related to it.

With this background, the present study was undertaken-

1. To compare the results of the various conventional IHC stains used as markers in ovarian germ cell tumours.

2. To understand the implications of the variability in staining in the diagnosis of these tumours.

\section{MATERIALS AND METHODS}

The study included all the ovarian germ cell tumours, which were diagnosed and reported from the Department of Pathology, Government Medical College, Trivandrum during the study period of one year. A total of fifty-five cases of ovarian germ cell tumours were included in this case series study. The morphological aspects of the tumours were studied. The tissue blocks of the relevant cases were cut and stained with Haematoxylin and Eosin stain and later with a panel of selected immunohistochemical markers. Each case was stained with PLAP, CD-117, OCT-4, CK, CD-30 and AFP markers, which are routinely used in the diagnosis of germ cell tumours. The result obtained with each case was documented and analysed.

\section{RESULTS}

We received a total of fifty-five cases of germ cell tumours during the study period of one year. The main bulk of them were the benign cystic teratomas with 36 out of the total 55 cases $(65.45 \%)$. This included two cases of struma ovarii. Nineteen cases of malignant germ cell tumours were received, six cases of which were discarded due to technical reasons. Teratoma cases were not included for marker study, as their diagnoses were very evident from gross and microscopic morphology and due to the irrelevance of using immunohistochemistry on them. Rest of the cases were stained with the popular IHC markers and their results were compared with the expected results.
Contrary to the usual positive PLAP staining expected in Dysgerminoma, the positivity was a mere $44.4 \%$ in our study. OCT-4 gave positive results, while PLAP gave negative results in necrotic areas of Dysgerminoma. Only 33.3\% cases of Yolk sac tumour gave positive results with AFP. OCT- 4 is a reliable marker for both dysgerminoma and embryonal carcinoma. But distinguishing between these two components will be difficult when they coexist in the same tumour. CD-30 was negative in all the three cases of embryonal carcinoma.

Initial diagnoses were based on the morphological pattern of the tumour. Dysgerminoma topped the list in incidence. All the markers in the panel gave expected result with dysgerminoma except one case. Three cases of yolk sac tumour were detected by morphological pattern. One among it was negative for AFP. There were three cases of embryonal carcinoma, of which two cases showed positivity for OCT-4. There was difficulty in distinguishing embryonal carcinoma from dysgerminoma, as both gave positive results with OCT4. None of the embryonal carcinoma gave positive results with CD-30, which is considered to be a crucial marker for its diagnosis.

Germ cell tumours other than teratomas are relatively rare. Moreover, there were no cases of malignant teratomas, choriocarcinoma or other rarer tumours during the study period. So a longer study period is recommended for an extensive study of IHC of these tumours.

Aberrant results were received in cases of dysgerminoma, yolk sac tumour and embryonal carcinoma. This stresses the importance of using positive control for all markers and adding newer markers in the study panel.

The very recent additions in the panel were not included in the study. More specific results are expected with the use of newer markers.

\begin{tabular}{|c|c|}
\hline Type of Tumour & Percentage \\
\hline Dysgerminoma & $61.5 \%$ \\
\hline Yolk sac tumour & $15.38 \%$ \\
\hline Embryonal carcinoma & $7.7 \%$ \\
\hline Mixed germ cell tumours & $15.38 \%$ \\
\hline \multicolumn{2}{|c|}{ Table 1. Types of Malignant Germ Cell Tumours } \\
\hline
\end{tabular}

\begin{tabular}{|c|c|c|c|c|c|c|c|}
\hline Case No. & Diagnosis by Morphology (H and E) & PLAP & CD-117 & OCT-4 & CK & CD-30 & AFP \\
\hline 1 & Dysgerminoma & + & + (vague) & + & $\mathrm{N}$ & $\mathrm{N}$ & $\mathrm{N}$ \\
\hline 2 & YST & $\mathrm{N}$ & $\mathrm{N}$ & $\mathrm{N}$ & $\mathrm{N}$ & $\mathrm{N}$ & + \\
\hline 3 & Embryonal carcinoma + YST & $\mathrm{N}$ & $\mathrm{N}$ & + & $\mathrm{N}$ & $\mathrm{N}$ & $\mathrm{N}$ \\
\hline 4 & Dysgerminoma & + & $\mathrm{N}$ & + & $\mathrm{N}$ & $\mathrm{N}$ & $\mathrm{N}$ \\
\hline 5 & Dysgerminoma + Embryonal Ca & $\mathrm{N}$ & $\mathrm{N}$ & + & $\mathrm{N}$ & $\mathrm{N}$ & $\mathrm{N}$ \\
\hline 6 & YST & $\mathrm{N}$ & $\mathrm{N}$ & $\mathrm{N}$ & $\mathrm{N}$ & $\mathrm{N}$ & $\mathrm{N}$ \\
\hline 7 & Dysgerminoma & + & + & + & $\mathrm{N}$ & $\mathrm{N}$ & $\mathrm{N}$ \\
\hline 8 & Embryonal carcinoma & + & $\mathrm{N}$ & $\mathrm{N}$ & $\mathrm{N}$ & $\mathrm{N}$ & $\mathrm{N}$ \\
\hline 9 & Dysgerminoma with necrosis & $\mathrm{N}$ & $\mathrm{N}$ & + & $\mathrm{N}$ & $\mathrm{N}$ & $\mathrm{N}$ \\
\hline 10 & Dysgerminoma & + & + (vague) & + & $\mathrm{N}$ & $\mathrm{N}$ & $\mathrm{N}$ \\
\hline 11 & Dysgerminoma & $\mathrm{N}$ & $\mathrm{N}$ & $\mathrm{N}$ & $\mathrm{N}$ & $\mathrm{N}$ & $\mathrm{N}$ \\
\hline 12 & Dysgerminoma & + (patchy) & + & $\mathrm{N}$ & $\mathrm{N}$ & $\mathrm{N}$ & $\mathrm{N}$ \\
\hline 13 & Dysgerminoma & + (patchy) & $\mathrm{N}$ & + & $\mathrm{N}$ & $\mathrm{N}$ & $\mathrm{N}$ \\
\hline
\end{tabular}




\begin{tabular}{|c|c|c|c|c|c|c|c|}
\hline Case No. & Diagnosis By H and E & PLAP & CD-117 & OCT-4 & CK & CD-30 & AFP \\
\hline 1 & Dysgerminoma & + & $+($ vague $)$ & + & $\mathrm{N}$ & $\mathrm{N}$ & $\mathrm{N}$ \\
\hline 4 & Dysgerminoma & + & $\mathrm{N}$ & + & $\mathrm{N}$ & $\mathrm{N}$ & $\mathrm{N}$ \\
\hline 5 & Dysgerminoma + Embryonal Ca & $\mathrm{N}$ & $\mathrm{N}$ & + & $\mathrm{N}$ & $\mathrm{N}$ & $\mathrm{N}$ \\
\hline 7 & Dysgerminoma & + & + & + & $\mathrm{N}$ & $\mathrm{N}$ & $\mathrm{N}$ \\
\hline 9 & Dysgerminoma with necrosis & $\mathrm{N}$ & $\mathrm{N}$ & + & $\mathrm{N}$ & $\mathrm{N}$ & $\mathrm{N}$ \\
\hline 10 & Dysgerminoma & + & $+($ vague $)$ & + & $\mathrm{N}$ & $\mathrm{N}$ & $\mathrm{N}$ \\
\hline 11 & Dysgerminoma & $\mathrm{N}$ & $\mathrm{N}$ & $\mathrm{N}$ & $\mathrm{N}$ & $\mathrm{N}$ & $\mathrm{N}$ \\
\hline 12 & Dysgerminoma & + (patchy) & + & $\mathrm{N}$ & $\mathrm{N}$ & $\mathrm{N}$ & $\mathrm{N}$ \\
\hline 13 & Dysgerminoma & + & $\mathrm{N}$ & $\mathrm{N}$ & $\mathrm{N}$ \\
\hline \multicolumn{2}{|l|}{ Table 3. Immunochemistry Profile of Dysgerminoma } &
\end{tabular}

\begin{tabular}{|c|c|c|c|c|c|c|}
\hline $\begin{array}{c}\text { Diagnosis by } \\
\text { H and E }\end{array}$ & PLAP & CD-117 & OCT-4 & CK & CD-30 & AFP \\
\hline YST & $\mathrm{N}$ & $\mathrm{N}$ & $\mathrm{N}$ & $\mathrm{N}$ & $\mathrm{N}$ & + \\
\hline $\begin{array}{c}\text { Embryonal } \\
\text { carcinoma + } \\
\text { YST }\end{array}$ & $\mathrm{N}$ & $\mathrm{N}$ & + & $\mathrm{N}$ & $\mathrm{N}$ & $\mathrm{N}$ \\
\hline YST & $\mathrm{N}$ & $\mathrm{N}$ & $\mathrm{N}$ & $\mathrm{N}$ & $\mathrm{N}$ & $\mathrm{N}$ \\
\hline Table 4. Immunohistochemical Profile of Yolk Sac Tumours \\
\hline
\end{tabular}

\begin{tabular}{|c|c|c|c|c|c|c|}
\hline $\begin{array}{c}\text { Diagnosis by } \\
\text { H and E }\end{array}$ & PLAP & CD-117 & OCT-4 & CK & CD-30 & AFP \\
\hline $\begin{array}{c}\text { Embryonal } \\
\text { carcinoma + YST }\end{array}$ & $\mathrm{N}$ & $\mathrm{N}$ & + & $\mathrm{N}$ & $\mathrm{N}$ & $\mathrm{N}$ \\
\hline $\begin{array}{c}\text { Dysgerminoma + } \\
\text { Embryonal Ca }\end{array}$ & $\mathrm{N}$ & $\mathrm{N}$ & + & $\mathrm{N}$ & $\mathrm{N}$ & $\mathrm{N}$ \\
\hline $\begin{array}{c}\text { Embryonal } \\
\text { Carcinoma }\end{array}$ & + & $\mathrm{N}$ & $\mathrm{N}$ & $\mathrm{N}$ & $\mathrm{N}$ & $\mathrm{N}$ \\
\hline \multicolumn{6}{|c|}{$\begin{array}{c}\text { Table 5. Immunohistochemical } \\
\text { Results in Embryonal Carcinoma }\end{array}$} \\
\hline
\end{tabular}

\section{DISCUSSION}

The morphology of all the germ cell tumours of ovary were studied. Benign cystic teratomas formed the main bulk of germ cell tumours with 36 out of the total 55 cases $(65.45 \%)$. Most cases of benign cystic teratomas were cystic tumours with mature elements alone. Two cases of struma ovarii, which contains mature thyroid components in teratomas were received during the study period. There were no cases of solid teratomas or immature teratomas. Teratoma cases were not included for marker study, as their diagnoses were very evident from gross and microscopic morphology and due to the irrelevance of using immunohistochemistry on them. There was a total of nineteen cases of malignant germ cell tumours in the study period. Six cases were discarded due to technical reasons.

Dysgerminoma was the most common malignant germ cell tumour with eight cases. There were two cases of yolk sac tumour and a single case of embryonal carcinoma. There were two mixed germ cell tumours, one with a combination of embryonal carcinoma and yolk sac tumour. The other was a combination of embryonal carcinoma and dysgerminoma. These diagnoses were made by morphology with haematoxylin and eosin stain. Table No. 1 shows the percentage of each tumour.

Further sections from all these tumours were stained with an array of IHC markers, PLAP, CD-117, OCT-4, CK, CD30 and AFP. The observations are shown in Table No. 2.

\section{Dysgerminoma}

On the basis of morphology, eight cases of pure dysgerminoma and a single case of dysgerminoma combined with embryonal carcinoma were diagnosed. One case had extensive areas of necrosis, which made the diagnosis by morphology itself difficult. The immunohistochemical profile of dysgerminoma is shown in Table No. 3.

The most characteristic finding is positive staining of tumour cells for placental alkaline phosphatase and the absence of it is said to be unusual in dysgerminoma. But PLAP expression is not a specific indicator of Dysgerminoma as other germ cell tumours and some carcinomas also express PLAP.1,2

In our study, three out of nine cases were negative for PLAP and 2 cases showed only patchy staining for PLAP. Dysgerminoma with extensive areas of necrosis was negative for PLAP. Another case of Dysgerminoma mixed with embryonal carcinoma by morphology also was negative for PLAP.

Studies on CD-117 claims it to show diffuse membranous positivity in nearly all cases. $4,5,6,7$ Since CD-117 is negative for embryonal carcinoma, it is considered a more specific marker for dysgerminoma. ${ }^{1}$ But in our study, five cases were negative for CD-117. Moreover, two cases showed only vague positivity.

The strong nuclear staining of OCT-4 makes it a more widely used and excellent marker for dysgerminoma. In the present study, only two cases of dysgerminoma showed negative staining for OCT-4. Even the dysgerminoma with necrosis showed positive staining with OCT-4, as is noted by Dabb. ${ }^{1}$

In this study on dysgerminoma, it is found that all the cases except one showed positive reaction with any one of the three IHC markers. PLAP was positive in $44.4 \%$ cases, whereas CD-117 were positive in $22.2 \%$ cases and OCT- 4 in $77.7 \%$ cases of Dysgerminoma. A single case of morphologically diagnosed dysgerminoma was negative for the three IHC markers, (Case No. 11 in Table 3) and it needs to be studied further with alternate newer IHC markers to reach a final diagnosis.

\section{Yolk Sac Tumour}

In the study, there were three cases of Yolk sac tumours diagnosed morphologically. One case was mixed with embryonal carcinoma. Only one case was positive with the marker Alpha-fetoprotein (33.3\% cases). The yolk sac component in the mixed tumour was negative for the specific marker. AFP is the specific marker for Yolk sac tumour, but it can be negative in post-chemotherapy cases. ${ }^{19}$ But none of 
our cases have such a history. Such negative cases can be stained with Glypican-3 and SALL-4.8,9 Table No. 4 shows the immunohistochemical profile of Yolk sac tumour.

\section{Embryonal Carcinoma}

Of the three cases of embryonal carcinoma, two cases were mixed germ cell tumours. Refer Table No. 5 for details. Both the mixed tumours showed positive staining for OCT-4. In the mixed germ cell tumour with dysgerminoma and embryonal carcinoma as components, both the components were positive for OCT-4 alone, which made the differentiation between the two difficult by IHC alone. ${ }^{20}$ Ideally, CD-117 comes in handy in such situations, but in our case the results were different. This calls for the use of newer markers like D2 40. CD-30, which is considered as the specific marker for embryonal carcinoma remained negative in all the three cases. ${ }^{16}$

\section{CONCLUSION}

In the present study on Immunohistochemical stains used in ovarian germ cell tumours, all the conventional markers were used. OCT- 4 was the most reliable marker in Dysgerminoma. AFP stained only $33.3 \%$ cases of Yolk sac tumour. CD-30 failed to stain any case of embryonal carcinoma. Another case of embryonal carcinoma was positive only for PLAP, which is contrary to what is expected. This scenario calls for the usage of more specific and reliable markers in these types of tumours. Future studies on these topics should include more number of cases and the stringent use of markers with positive controls.

\section{ACKNOWLEDGEMENTS}

My sincere thanks to Dr. Santha Sadasivan, Retired Professor of Pathology, Govt. Medical College, Trivandrum and Dr. Krishna Balachandran, Professor, Department of Pathology, Govt. Medical College, Trivandrum, for encouraging me to proceed with this study and providing valuable suggestions. I express my sincere thanks to Mr. Dileep, Senior Scientific Officer and Mrs. Nisha, Lab Technician, Department of Pathology, Govt. Medical College, Trivandrum, for their help in the preparation of the IHC slides.

\section{REFERENCES}

[1] Dabb D. Diagnostic immunohistochemistry. 2nd edn. Churchill Livingston 2006.

[2] Nogales FF, Dulcey I, Preda O. Germ cell tumors of ovary: an update. Arch Pathol Lab Med 2014;138(3):351-62.

[3] Iczkowski KA, Butler SL, Shanks JH, et al. Trials of new germ cell immunohistochemical stains in 93 extragonadal and metastatic germ cell tumors. Hum Pathol 2008;39(2):275-81.

[4] Cheng L, Roth LM, Zhang S, et al. KIT gene mutation and amplification in dysgerminoma of the ovary. Cancer 2011;117(10):2096-103.

[5] Gibson PC, Cooper K. CD117 (KIT): a diverse protein with selective applications in surgical pathology. Adv Anat Pathol 2002;9(1):65-9.
[6] Leroy X, Augusto D, Leteurtre E, et al. CD30 and CD117 (c-kit) used in combination are useful for distinguishing embryonal carcinoma from seminoma. J Histochem Cytochem 2002;50(2):283-5.

[7] Sever M, Jones TD, Roth LM, et al. Expression of CD117 (c-kit) receptor in dysgerminoma of the ovary: diagnostic and therapeutic implications. Mod Pathol 2005;18(11):1411-6.

[8] Nogales FF, Preda 0, Nicolae A. Yolk sac tumours revisited: a review of their many faces and names. Histopathology 2012;60(7):1023-33.

[9] Kandil DH, Cooper K. Glypican-3: a novel diagnostic marker for hepatocellular carcinoma and more. Adv Anat Pathol 2009;16(2):125-9.

[10] Zynger DL, Everton MJ, Dimov ND, et al. Expression of glypican 3 in ovarian and extragonadal germ cell tumors. Am J Clin Pathol 2008;130(2):224-30.

[11] Preda O, Nicolae A, Aneiros-Fernandez J, et al. Glypican 3 is a sensitive, but not a specific, marker for the diagnosis of yolk sac tumours. Histopathology 2011;58(2):314-5.

[12] Esheba GE, Pate LL, Longacre TA. Oncofetal protein glypican-3 distinguishes yolk sac tumor from clear cell carcinoma of the ovary. Am J Surg Pathol 2008;32(4):600-7.

[13] Niehans GA, Manivel JC, Copland GT, et al. Immunohistochemistry of germ cell and trophoblastic neoplasms. Cancer 1988;62(6):1113-23.

[14] Ramalingam P, Malpica A, Silva EG, et al. The use of cytokeratin 7 and EMA in differentiating ovarian yolk sac tumors from endometrioid and clear cell carcinomas. Am J Surg Pathol 2004;28(11):1499-505.

[15] Looijenga LH, Stoop H, de Leeuw HP, et al. POU5F1 (OCT3/4) identifies cells with pluripotent potential in human germ cell tumors. Cancer Res 2003;63(9):2244-50.

[16] Pallesen G, Hamilton-Dutoit SJ. Ki-1 (CD30) antigen is regularly expressed by tumor cells of embryonal carcinoma. Am J Pathol 1988;133(3):446-50.

[17] McCluggage WG, Ashe P, McBride H, et al. Localization of the cellular expression of inhibin in trophoblastic tissue. Histopathology 1998;32(3):252-6.

[18] Pelkey TJ, Frierson HF, Mills SE, et al. Detection of the alpha-subunit of inhibin in trophoblastic neoplasia. Hum Pathol 1999;30(1):26-31.

[19] Damjanov I, Amenta PS, Zarghami F. Transformation of an AFP-positive yolk sac carcinoma into an AFPnegative neoplasm: evidence for in vivo cloning of the human parietal yolk sac carcinoma. Cancer 1984;53(9):1902-7.

[20] Rijlaarsdam MA, van Herk HA, Gillis AJ, et al. Specific detection of OCT3/ 4 isoform A/B/B1 expression in solid (germ cell) tumours and cell lines: confirmation of 0CT3/4 specificity for germ cell tumours. Br J Cancer 2011;105(6):854-63. 